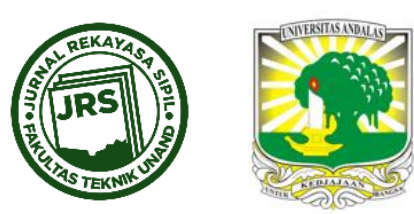

\title{
RELEVANSI UNIT KOMPETENSI INSINYUR SIPIL PADA BIDANG PEKERJAAN DAN PENGARUHNYA TERHADAP KINERJA PROFESI
}

\author{
INDRI MISWAR ${ }^{1}$, BENNY HIDAYAT ${ }^{2}$, TAUFIKA OPHIYANDRI ${ }^{3}$ \\ ${ }^{1}$ Prodi Magister Teknik Sipil, Fakultas Teknik,Universitas Andalas (indri_miswar@yahoo.co.id) \\ ${ }^{2}$ Jurusan Teknik Sipil, Fakultas Teknik, Universitas Andalas (\bennyhidayat@ft.unand.ac.id) \\ ${ }^{3}$ Jurusan Teknik Sipil, Fakultas Teknik, Universitas Andalas (ophiyandri@ft.unand.ac.id) \\ Naskah diterima : 11 Agustus 2017. Disetujui: 7 Oktober 2017. Diterbitkan : 22 Oktober 2017
}

\begin{abstract}
ABSTRAK
Memasuki Era Pasar Bebas (MEA) yang telah berlangsung sejak tahun 2015 merupakan tahapan baru bagi perekonomian di wilayah Asia Tenggara terutama Indonesia. Dalam hal ini Insinyur merupakan tenaga ahli yang sangat besar peranannya dalam menyelesaikan suatu pembangunan. Oleh karena itu kualitas seorang Insinyur sebagai lini terdepan yang berhadapan langsung dengan permasalahan yang berhubungan dengan pelaksanaan pekerjaan harus memenuhi berbagai kriteria salah satunya yaitu kompetensi. Tujuan penelitian ini untuk mengidentifikasi relevansi unit kompetensi Insinyur Sipil pada bidang pekerjaan dan pengaruhnya terhadap kinerja profesi pada bidang perencana, pengawas dan pelaksana konstruksi di kota Padang. Metode penelitian yang digunakan adalah metode survey dan metode wawancara untuk validasi hasil penelitian. Analisa data mengunakan analisis data non parametrik dan analisis data statistik deskriptif. Dari hasil analisa diperoleh bahwa rata-rata nilai tertinggi relevansi dan pengaruh unit dan elemen kompetensi di atas skala 4 yang artinya sangat relevan terhadap bidang pekerjaan dan sangat berpengaruh terhadap kinerja profesi, aspek unit kompetensi mempunyai hubungan yang signifikan dengan kinerja profesi Insinyur Sipil (kinerja profesi Insinyur Sipil pada bidang pekerjaannya akan baik apabila memiliki unit kompetensi yang baik).
\end{abstract}

Kata kunci : Kompetensi, Insinyur Sipil, Kinerja Pekerjaan, Non Parametrik, Statistik Deskriptif

\section{PENDAHULUAN}

Dalam menghadapi Era Pasar Bebas segala bidang perekonomian di Indonesia harus segera berbenah untuk dapat bersaing dengan pihak-pihak asing baik itu pemerintah ataupun swasta. Dengan ketersediaan sumber daya manusia yang cukup banyak di Indonesia, maka aspek SDM merupakan salah satu bagian yang perlu diperhatikan dalam menghadapi MEA, maka kualitas seorang Insinyur sebagai lini terdepan yang berhadapan langsung dengan permasalahan yang berhubungan dengan pelaksanaan pekerjaan, harus memenuhi berbagai kriteria. Ahadzie (2009) menuliskan kompetensi merupakan faktor yang sangat penting bagi seorang Insinyur Sipil dalam menghasilkan kinerja yang baik. 
Sulistiawati (2012) menyatakan rendahnya kualitas tenaga kerja di Indonesia selain karena faktor pendidikan formal, juga disebabkan oleh ketersediaan lembaga pelatihan untuk meningkatkan kualitas pekerja masih belum memadai, diikuti dengan rendahnya kompetensi tenaga kerja. Karena pentingnya kompetensi tersebut maka penelitian ini bertujuan untuk mengidentifikasi unit dan elemen kompetensi Insinyur Sipil dan mengetahui relevansinya terhadap bidang pekerjaan serta pengaruhnya terhadap kinerja profesi Insinyur Sipil tersebut. Penelitian ini akan dilakukan pada bidang perencanaan (perusahaan Semen Padang), bidang pengawasan (Dinas PU) dan bidang pelaksanaan (Kontraktor) yang ada di kota Padang.

\section{TINJAUAN PUSTAKA}

\subsection{Definisi Kompetensi}

Berikut beberapa pengertian kompetensi yang diajukan oleh Nofiyar (2013) berdasarkan hasil penelitian dan atas pengamatan : 1. Pengertian kompetensi atau kemampuan sebagai suatu sifat dasar seseorang yang dengan sendirinya berkaitan dengan pelaksanaan suatu pekerjaan secara efektif atau berhasil guna. An underlaying characteristic of an individual which is causally related to effective or superior performance in a job (Boyatzis dalam Spencer et al, 1994:6). 2. Pengertian kompetensi sebagai karakteristik dasar seseorang dan menunjukkan perilaku disimpulkan dari situasi tertentu dan bertahan dalam jangka waktu yang cukup lama. Competency are underlaying characteristics of people and indicate ways of behaving generalizing across situations and enduring for a reasonably long period of time (Spencer and Spencer, 1993:9). 3. Kompetensi didefinisikan sebagai aspek-aspek pribadi dari seorang pekerja yang memungkinkan dia untuk mencapai kinerja yang superior. Aspekaspek pribadi ini termasuk sifat, motif-motif, sistem nilai, sikap, pengetahuan dan keterampilan. Kompetensi-kompetensi akan mengarahkan tingkah laku, sedangkan tingkah laku akan menghasilkan kinerja (Kamus Kompetensi LOMA, 1998:1).

Sesuai uraian berbagai pengertian kompetensi di atas, berkembang pengertian kompetensi profesional. Persatuan Insinyur Indonesia (PII) menyatakan kompetensi profesional adalah kemampuan kerja individu yang telah teruji dan diakui komunitas profesinya dalam melaksanakan kerja profesional. Kompetensi profesional PII meliputi 3 (tiga) aspek seperti terlihat pada Gambar 1. di bawah ini :

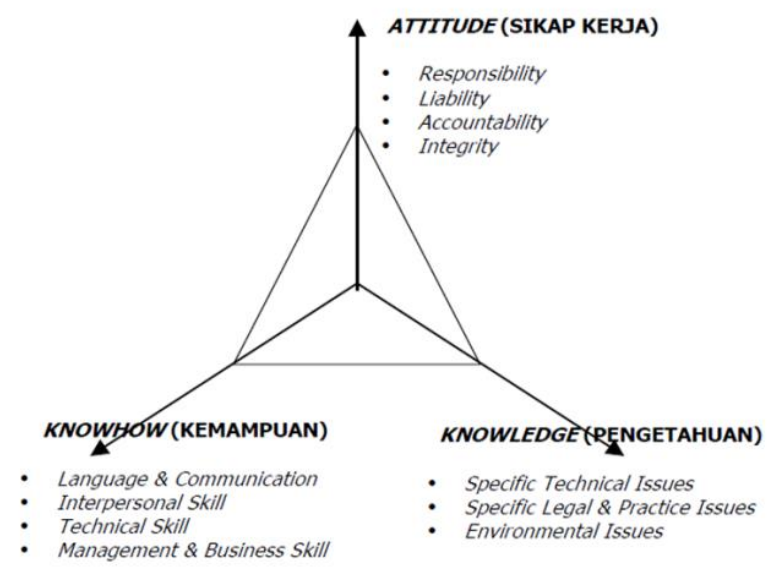

Gambar 1. Kompetensi profesional persatuan insinyur Indonesia (PII) (Sumber : Elizarosma, 2008) 
Dari Gambar 1 di atas terlihat 3 aspek kompetensi yang dinyatakan oleh PII yaitu aspek attitude (sikap kerja), aspek knowhow (kemampuan), dan aspek knowledge(pengetahuan).

Kompetensi knowledgemenurut Boyatzis (2007), menganalogikan kompetensi knowledgesebagai kompetensi kognitif dimana kompetensi ini memiliki kemampuan untuk berfikir atau menganalisa informasi dan situasi yang akan mengarahkan atau menyebabkan kesuksesan atau kinerja yang superior.

Nofiyar (2013) dalam rangka mencapai kinerja waktu proyek yang baik, seorang civil engineer harus memiliki skill yang berkaitan dengan pengelolaan pekerjaan desain. Skill didefinisikan sebagai suatu kemampuan untuk menterjemahkan pengetahuannya kedalam tindakan. Skill adalah kemampuan atau keterampilan yang didapatkan dari praktik dan pelatihan. Skill yang paling penting dari seorang civil engineer yang efektif adalah kepemimpinan, pengambilan keputusan, dan komunikasi.

Dalam bekerja setiap Insinyur Sipil pada semua tingkat melakukan proses manajemen (perencanaan, pengorganisasian, pengarahan, dan pengendalian), pada setiap pekerjaan berbeda dalam hal alokasi waktu untuk aktivitas mereka.

\begin{tabular}{|l|l|}
\hline $\begin{array}{l}\text { Manajemen } \\
\text { Tingkat Atas }\end{array}$ & $\begin{array}{l}\text { Keterampilan } \\
\text { konseptual }\end{array}$ \\
\hline $\begin{array}{l}\text { Manajemen } \\
\text { Mingkat }\end{array}$ &
\end{tabular}

Gambar 2. Tingkatan manajemen dan keterampilan yang dibutuhkan (Hanafi, 2015)

Gambar 2 menunjukan bahwa manajer puncak lebih banyak membutuhkan kemampuan konseptual, sedangkan manajer operasional lebih banyak membutuhkan kemampuan teknis. Namun, setiap manajer harus mempunyai ketiga macam keterampilan tersebut meskipun dengan penekanan yang berbeda-beda.

Menurut Nofiyar (2013) dalam tulisannya menyatakan bahwa unsur kompetensi yang ketiga yaitu sikap, yang merupakan hal yang penting dan harus dimiliki oleh seorang civil engineer agar dapat mengerjakan dan menyelesaikan pekerjaan dengan baik. Pembagian variabel kompetensi yang di ambil dari beberapa literatur yaitu variabel pengetahuan yang terdiri dari : ilmu pengetahuan teknik sipil, kemampuan menerapkan ilmu dasar teknik sipil, pengetahuan bidang, pengetahuan dalam organisasi, pengetahuan spesifik dari jabatan. Variabel keterampilan terdiri dari : keterampilan mengelola diri sendiri, keterampilan berbahasa, keterampilan kuantitatif, keterampilan analitis, memperhatikan secara rinci, dan keterampilan teknis. Variabel yang terakhir yaitu sikap yang terdiri dari : komunikasi antar karyawan, membangun dan memelihara hubungan, memotivasi orang lain, dapat diandalkan, motivasi pribadi, pengalaman, orientasi belajar yang berkelanjutan, dan keluwesan.

\subsection{Kinerja Karyawan}


Rivai\&Basri (2004) dan Harsuko (2011) (dalam Aini, 2014) menyatakan bahwa kinerja apabila dikaitkan dengan performance sebagai kata benda (noun), maka pengertian performance atau kinerja adalah hasil kerja yang dapat dicapai oleh seseorang atau kelompok orang dalam suatu perusahaan sesuai dengan wewenang dan tanggung jawab masing-masing dalam upaya pencapaian tujuan perusahaan secara ilegal, tidak melanggar hukum dan tidak bertentangan dengan moral dan etika.

Aini (2014) menyatakan kriteria kinerja adalah dimensi-dimensi pengevaluasian kinerja seseorang pemegang jabatan, suatu tim, dan suatu unit kerja. Secara bersama-sama dimensi itu merupakan harapan kinerja yang berusaha dipenuhi individu dan tim guna mencapai strategi organisasi.

Menurut Schuler dan Jackson (2004) dan Harsuko (2011) (dalam Aini, 2014) bahwa ada 3 jenis dasar kriteria kinerja yaitu: 1. Kriteria berdasarkan sifat memusatkan diri pada karakteristik pribadi seseorang karyawan. Loyalitas, keandalan, kemampuan berkomunikasi, dan keterampilan memimpin merupakan sifat-sifat yang sering dinilai selama proses penilaian. Jenis kriteria ini memusatkan diri pada bagaimana seseorang, bukan apa yang dicapai atau tidak dicapai seseorang dalam pekerjaanya. 2. Kriteria berdasarkan perilaku terfokus pada bgaimana pekerjaan dilaksanakan. Kriteria semacam ini penting sekali bagi pekerjaan yang membutuhkan hubungan antar personal. Sebagai contoh apakah SDM-nya ramah atau menyenangkan. 3. Kriteria berdasarkan hasil, kriteria ini semakin populer dengan makin ditekannya produktivitas dan daya saing internasional. Kriteria ini berfokus pada apa yang telah dicapai atau dihasilkan ketimbang bagaimana sesuatu dicapai atau dihasilkan.

\subsection{Hubungan Kompetensi dan Kinerja}

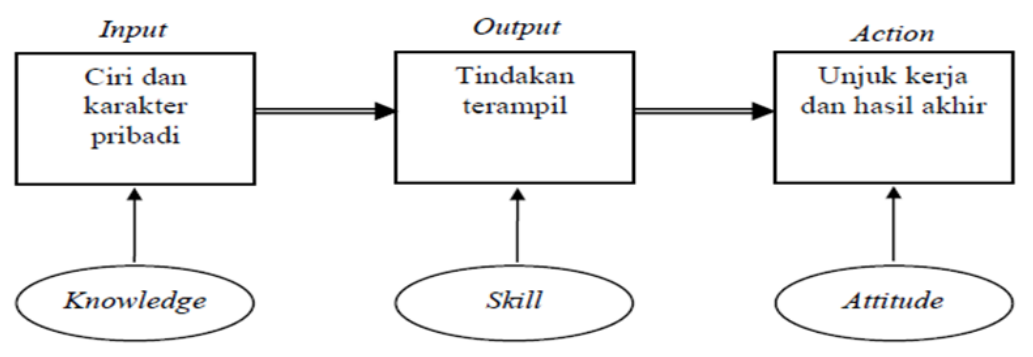

Gambar 3. Karakteristik dasar kompetensi (Rimsky,2008:49 dalam Nofiyar,2013)

Pada Gambar 3 di atas dapat dilihat pola hubungan dari kompetensi terhadap hasil dari sebuah pekerjaan yang akan berpengaruh pada kinerja yang dihasilkan karyawan pada perusahaannya. Ketiga aspek kompetensi yaitu knowledge, skill dan attitude saling berhubungan pada input dan output sikap seorang karyawan sehingga dapat dirasakan langsung pada tindakan nya dalam perilaku sehari-hari.

\section{METODE PENELITIAN}

Tahap awal dalam penyusunan dan pengumpulan data untuk mengetahui variabel kompetensi yaitu studi literatur dengan membuat tabel variabel kompetensi dari berbagai sumber literature dan jurnal. Berdasarkan literatur kesepakatan umum bahwa elemen kompetensi terdiri dari pengetahuan (knowledge), keterampilan (skill) dan sikap atau perilaku (attitude), unit dan elemen kompetensinya, yaitu : 1. Pengetahuan (knowledge): 
ilmu pengetahuan teknik sipil (terdiri dari: pengetahuan dasar, struktur bangunan beton, mekanika tanah, keairan, struktur baja dan kayu, manajemen konstruksi, transportasi), pengetahuan penerapan ilmu teknik sipil (terdiri dari: manajemen keselamatan dan kesehatan kerja (K3), manajemen lingkungan, manajemen risiko, mengakses pengetahuan dan kepakaran), pengetahuan spesifik dari jabatan (terdiri dari: perencanaan bangunan sipil, perencanaan proses manufaktur/produksi, pengetahuan teknis, mengelola sumber daya). 2 . Keterampilan (skill): keterampilan mengelola diri sendiri (terdiri dari: kepercayaan diri, manajemen diri, manajemen waktu), keterampilan berbahasa (terdiri dari: keterampilan dalam presentasi, pemahaman membaca, keterampilan menulis, komunikasi yang efektif, keterampilan berbahasa asing), keterampilan analitis (terdiri dari: perencanaan dan pengorganisasian, keterampilan pengendalian, menganalisa permasalahan, pengambilan keputusan, keterampilan kepemimpinan), keterampilan teknis (terdiri dari: menyajikan informasi dalam tabel dan grafik, orientasi rinci, membaca dan memahami gambar teknik, menyusun dokumen desain, menyusun dokumen kontrak, mengaplikasikan software teknik sipil). 3. Sikap (attitude): komunikasi antar karyawan, membangun dan memelihara hubungan, memotivasi orang lain, dapat diamdalkan, motivasi pribadi, pengalaman, orientasi belajar yang berkelanjutan, keluwesan, kreatifitas.

Metode survey dilakukan pada responden Insinyur Sipil yang telah memiliki pengalaman di atas 1 tahun yaitu pengumpulan data dilakukan dengan mengadakan kuesioner (daftar pertanyaan) yang disampaikan langsung kepada responden dilengkapi dengan pertanyaanpertanyaan yang terstruktur terhadap responden untuk mendapatkan data-data primer yang diperlukan. Peneliti membagi kuesioner menjadi 2 bagian: kuesioner unit Kompetensi Insinyur Sipil, kuesioner kinerja profesi. Sebelum dilakukan survey data terlebih dahulu dilakukan pilot survey kepada 5 orang responden untuk melihat tingkat pemahaman responden dan untuk memperoleh masukan terhadap kuesioner survey. Pengumpulan data kuesioner dilakukan pada tiga instansi dengan total yang disebarkan 100 buah kuesioner dan kuesioner yang kembali berjumlah 83 buah terdiri dari 27 buah kuesioner pada instansi Semen Padang, 28 buah kuesiner pada instansi dinas PU dan 28 buah kuesioner pada perusahaan kontraktor.

Setelah kuesioner terkumpul dilakukan kegiatan tabulasi dalam hal ini : 1. Coding yaitu pembahasan kode untuk setiap data yang telah diedit. 2. Skoring yaitu pemberian skor terhadap jawaban responden untuk memperoleh data kuantitatif yang diperlukan. Dari tahap tabulasi kegiatan akan didapat 2 data kuesioner : 1. Data relevansi unit kompetensi Insinyur Sipil (variabel X). 2. Data pengaruh terhadap kinerja profesi (variabel Y).

Untuk mendapatkan data yang akan dianalisa, digunakan kuesioner yang berisi pertanyaan tentang variabel unit kompetensi yang dibutuhkan oleh Insinyur Sipil. Kompetensi dinilai dari aspek pengetahuan, aspek keterampilan, dan aspek sikap dengan menggunakan penilaian 5 skala relevansi (Chandra, 2016) yaitu : 1. Skala 1 menunjukkan sangat tidak relevan, 2. Skala 2 menunjukkan tidak relevan, 3. Skala 3 menunjukkan netral, 4. Skala 4 menunjukkan relevan, 5 . Skala 5 menunjukkan sangat relevan. Dalam penelitian ini, skala ordinal yang digunakan untuk mengukur tingkat pengaruh dari variabel teknikal kompetensi adalah jenjang/kategori 1-5. Penentuan jumlah jenjang/kategori ini didasarkan pada kondisi responden, dimana sebagian besar responden tidak dapat melaksanakan pemilihan untuk mengisi skala apabila ketegorinya terlalu banyak. Keterangan pengaruh variabel kompetensi Insinyur Sipil terhadap kinerja/ produktifitas profesi (Nofiyar, 2013) yaitu: 
Tabel 1. Skala pengaruh kompetensi insinyur sipil terhadap kinerja/produktifitas profesi

\begin{tabular}{lll}
\hline Skala & Penilaian & Keterangan \\
\hline 1 & Tidak Berpengaruh & $\begin{array}{l}\text { Relevansi unit kompetensi tidak berpengaruh terhadap kinerja } \\
\text { profesi }\end{array}$ \\
\hline 2 & Kurang Berpengaruh & $\begin{array}{l}\text { Relevansi unit kompetensi kurang berpengaruh terhadap kinerja } \\
\text { profesi }\end{array}$ \\
\hline 3 & Cukup Berpengaruh & $\begin{array}{l}\text { Relevansi unit kompetensi cukup berpengaruh terhadap kinerja } \\
\text { profesi }\end{array}$ \\
\hline 4 & Berpengaruh & Relevansi unit kompetensi berpengaruh terhadap profesi \\
\hline 5 & Sangat Berpengaruh & $\begin{array}{l}\text { Relevansi unit kompetensi sangat berpengaruh terhadap kinerja } \\
\text { profesi }\end{array}$ \\
\hline
\end{tabular}

Dari data survey yang diperoleh setelah dilakukan pengujian maka dilakukan identifikasi komponen unit kompetensi apa saja yang mempengaruhi kinerja profesi dari karyawan tersebut pada bidang pekerjaan yang dilakukannya. Setelah diperoleh hasil bagaimana relevansi dan pengaruh unit kompetensi Insinyur Sipil pada bidang pekerjaan terhadap kinerja profesi maka dilakukan validasi hasil survey tersebut dengan melakukan wawancara kepada 6 orang yang berada pada level manajerial.

\section{HASIL DAN PEMBAHASAN}

\subsection{Profil Responden}

Tabel 2. Data responden penelitian

\begin{tabular}{|c|c|c|c|c|}
\hline No. & Profil Responden & Kriteria & $\begin{array}{l}\text { Persentase } \\
(\%)\end{array}$ & $\begin{array}{l}\text { Jumlah } \\
\text { (Orang) }\end{array}$ \\
\hline \multirow{2}{*}{1.} & \multirow{2}{*}{ Jenis Kelamin } & Perempuan & $24 \%$ & 20 \\
\hline & & Laki-Laki & $76 \%$ & 63 \\
\hline \multirow{3}{*}{2.} & \multirow{3}{*}{ Umur } & 21-30 Thn & $51 \%$ & 42 \\
\hline & & 31-40 Thn & $38 \%$ & 32 \\
\hline & & 41-50 Thn & $11 \%$ & 9 \\
\hline \multirow{3}{*}{3.} & \multirow{3}{*}{$\begin{array}{l}\text { Jabatan Pada } \\
\text { Manajemen }\end{array}$} & Top-Management & $2 \%$ & 2 \\
\hline & & $\begin{array}{l}\text { Middle- } \\
\text { Management }\end{array}$ & $9 \%$ & 7 \\
\hline & & $\begin{array}{l}\text { Lower- } \\
\text { Management }\end{array}$ & $89 \%$ & 74 \\
\hline \multirow{3}{*}{4.} & \multirow{3}{*}{ Lama Pengalaman Kerja } & $\geq 11$ Thn & $14 \%$ & 12 \\
\hline & & $3-10$ Thn & $74 \%$ & 61 \\
\hline & & $1<\mathrm{x} \leq 2$ Thn & $12 \%$ & 10 \\
\hline \multirow{3}{*}{5.} & \multirow{3}{*}{ Tingkat Pendidikan } & Pasca(S2/S3) & $7 \%$ & 6 \\
\hline & & Sarjana $(\mathrm{S} 1)$ & $71 \%$ & 59 \\
\hline & & Diploma(D3) & $22 \%$ & 18 \\
\hline
\end{tabular}

\subsection{Pengujian Instrumen Penelitian}

\subsubsection{Uji Validitas Dan Uji Reliabilitas}

Dari hasil uji validitas analisa korelasi Pearson menunjukan bahwa instrument penelitian yang digunakan dapat dinyatakan valid dengan nilai probabilitas (sig 2-tailed) $\leq 0,05$ yang berarti item tersebut mampu mengukur elemen faktor dalam peneitian. Hasil uji reliabilitas kedua variabel pada statistik nilai Cronbach's Alpha berkisar antara 0.974-0.975. Karena nilai Cronbach's Alpha diatas 0.8 maka alat ukur dalam penelitian dapat dikatakan baik dan reliable. 


\subsubsection{Tes Normalitas dan Homogenitas Data}

Dari hasil tes normalitas dilakukan untuk melihat distribusi data penelitian, hasil pengujian data diperoleh nilai Sig. pada uji Kolmogorov-Smirnov sebesar .000 sehingga lebih kecil dari 0.05, maka dapat disimpulkan bahwa data nilai variabel kompetensi berasal dari populasi yang berdistribusi tidak normal. Sehingga digunakan analisis data non parametrik. Sementara hasil pengujian homogenitas data di peroleh bahwa variabel kompetensi berasal dari populasi yang bervarian homogen untuk semua variabel, kecuali beberapa variabel berikut, karena sig < 0.05 yang berarti data variabel kompetensi tidak berasal dari populasi yang bervarian homogen, yaitu : relevansi kompetensi pengetahuan teknis, relevansi kompetensi percaya diri, pengaruh kompetensi manajemen diri, pengaruh kompetensi manajemen waktu, relevansi dan pengaruh kompetensi perencanaan pengorganisasian, relevansi kompetensi membaca\&memahami gambar teknik, pengaruh kompetensi mengaplikasikan software teknik sipil.

\subsection{Analisis Data Penelitian}

\subsubsection{Analisis Data Statistik Deskriptif}

Untuk mengolah berbagai type statistik analisa ini menggunakan bantuan program SPSS versi 22. Setiap jawaban dari responden mengenai variabel kompetensi dan pengaruhnya terhadap kinerja pekerjaan akan dikelompokan menjadi beberapa skala jawaban yaitu :

Tabel 3. Skala jawaban responden

\begin{tabular}{lll}
\hline Skala & Relevansi Unit \& Elemen Kompetensi & Pengaruh Pada Kinerja Profesi \\
\hline $4-5$ & Sangat Relevan & Sangat Berpengaruh \\
\hline $3-4$ & Relevan & Berpengaruh \\
\hline $2-3$ & Kurang Relevan & Kurang Berpengaruh \\
\hline $1-2$ & Tidak Relevan & Tidak Berpengaruh \\
\hline
\end{tabular}

Sesuai skala pada Tabel 3 di atas maka dapat dilihat bahwa rata- rata jawaban dari responden berada pada range nilai 3 sampai 5 untuk setiap variabelnya. Sehingga dapat disimpulkan bahwa setiap variabel unit kompetensi berkaitan pada bidang pekerjaan dan berpengaruh terhadap kinerja profesi Insinyur Sipil tersebut.

\subsubsection{Relevansi Unit Kompetensi Insinyur Sipil Pada Bidang Pekerjaan}

Tabel 4. Nilai Relevansi Maksimum Unit Kompetensi

\begin{tabular}{|c|c|c|c|c|}
\hline \multirow{2}{*}{ No. } & \multirow{2}{*}{$\begin{array}{l}\text { Unit Kompetensi } \\
\text { Insinyur Sipil }\end{array}$} & \multicolumn{3}{|c|}{ Bidang Pekerjaan / Nilai Mean Maksimum } \\
\hline & & Perencana & Pengawas & Pelaksana \\
\hline 1 & Pengetahuan (Knowledge) & & & \\
\hline a. & $\begin{array}{l}\text { Ilmu Pengetahuan Teknik } \\
\text { Sipil }\end{array}$ & 4.13 & 4.03 & 4.13 \\
\hline b. & $\begin{array}{l}\text { Pengetahuan Penerapan } \\
\text { Ilmu Dasar Teknik Sipil }\end{array}$ & 3.89 & 3.69 & 3.94 \\
\hline c. & $\begin{array}{l}\text { Pengetahuan Spesifik dari } \\
\text { Jabatan }\end{array}$ & 4.06 & 3.91 & 4.04 \\
\hline 2 & Keterampilan (Skill) & & & \\
\hline a. & $\begin{array}{l}\text { Keterampilan } \text { Mengelola } \\
\text { Diri Sendiri }\end{array}$ & 4.16 & 4.17 & 4.48 \\
\hline b. & Keterampilan Berbahasa & 3.95 & 3.74 & 4.02 \\
\hline
\end{tabular}




\begin{tabular}{lllll}
\hline \multirow{2}{*}{ No. } & \multirow{2}{*}{$\begin{array}{l}\text { Init } \\
\end{array}$} & Kompetensi & \multicolumn{3}{l}{ Bidang Pekerjaan / Nilai Mean Maksimum } \\
\cline { 3 - 5 } & Perencana & Pengawas & Pelaksana \\
\hline c. & Keterampilan Analitis & 4.01 & 4.00 & 4.18 \\
\hline d. & Keterampilan Teknis & 4.11 & 4.14 & 4.22 \\
\hline 3 & Sikap (Attitude) & 4.12 & 3.92 & 4.09 \\
\hline
\end{tabular}

Pada Tabel 4 di atas dapat di lihat bahwa nilai rata-rata maksimum relevansi setiap unit kompetensi pada bidang perencana, pengawas dan pelaksana berada pada skala di atas 3 yang artinya unit kompetensi tersebut relevan dan sangat relevan terhadap bidang pekerjaan yaitu perencanaan, pengawasan dan pelaksanaan konstruksi.

Tabel 5. Nilai Relevansi Maksimum Unit Kompetensi

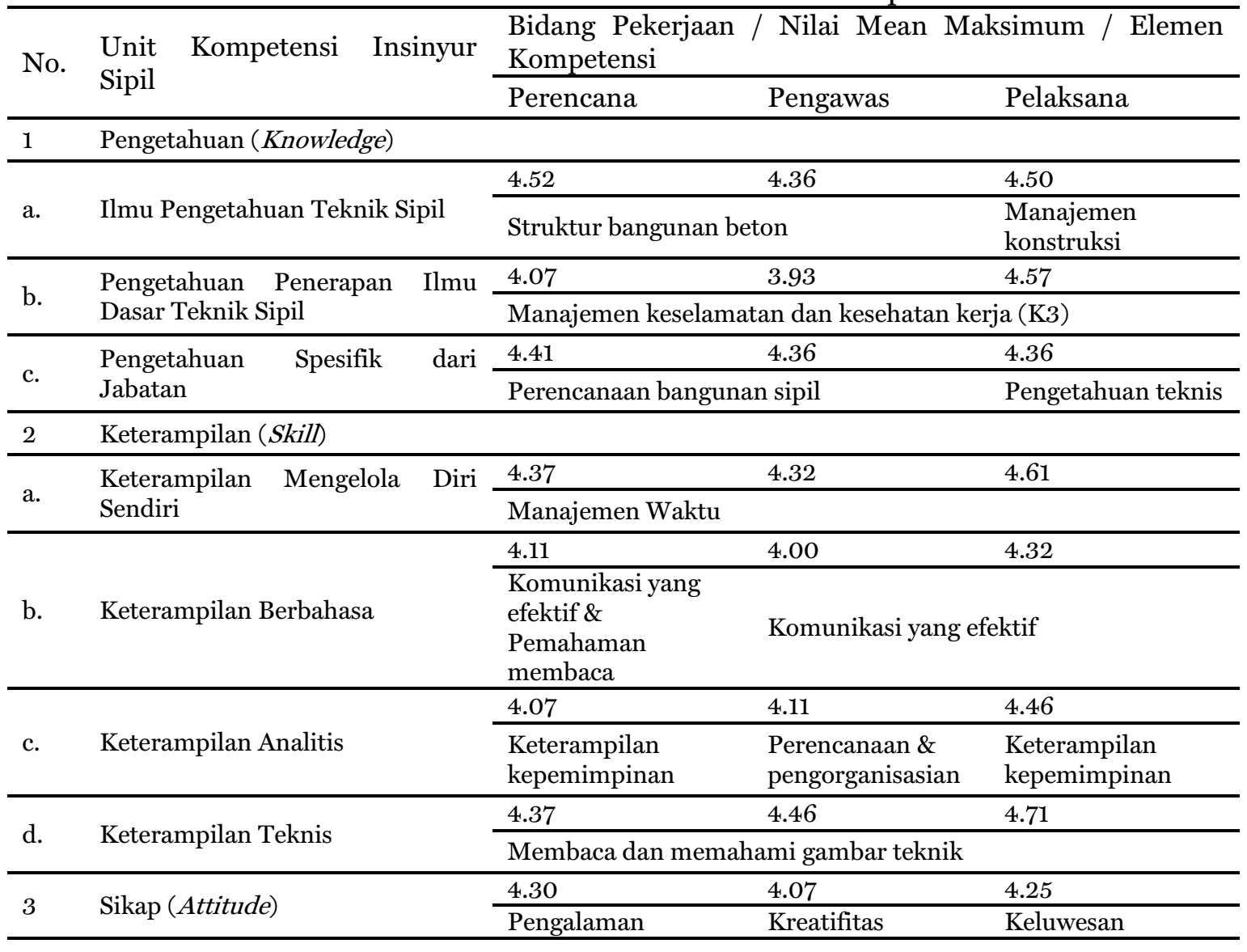

Pada Tabel 5 terlihat nilai rata-rata maksimum relevansi setiap elemen kompetensi pada bidang perencana, pengawas dan pelaksana berada pada skala relevan dan sangat relevan. Nilai rata-rata maksimum relevansi yang tertinggi sebesar 4.71, yang artinya tingkat relevansi elemen kompetensi membaca dan memahami gambar teknik sangat relevan pada bidang pekerjaan pelaksana konstruksi.

4.3.1.2 Pengaruh Unit Kompetensi Insinyur Sipil Terhadap Kinerja Profesi 
Tabel 6. Nilai Maksimum Pengaruh Unit Kompetensi Terhadap Kinerja Profesi

\begin{tabular}{|c|c|c|c|c|}
\hline \multirow{2}{*}{ No. } & \multirow{2}{*}{$\begin{array}{lr}\text { Pengaruh } & \text { Unit } \\
\text { Kompetensi } & \text { Terhadap } \\
\text { Kinerja Profesi } & \\
\end{array}$} & \multicolumn{3}{|c|}{ Bidang Pekerjaan/ Nilai Mean Maksimum } \\
\hline & & Perencana & Pengawas & Pelaksana \\
\hline 1 & Pengetahuan (Knowledge & & & \\
\hline a. & $\begin{array}{l}\text { Ilmu Pengetahuan } \\
\text { Teknik Sipil }\end{array}$ & 4.21 & 3.75 & 3.80 \\
\hline b. & $\begin{array}{l}\text { Pengetahuan } \\
\text { Penerapan Ilmu Dasar } \\
\text { Teknik Sipil }\end{array}$ & 3.88 & 3.53 & 3.67 \\
\hline c. & $\begin{array}{ll}\begin{array}{l}\text { Pengetahuan } \\
\text { dari Jabatan }\end{array} & \text { Spesifik } \\
\end{array}$ & 4.20 & 3.85 & 3.81 \\
\hline 2 & Keterampilan (Skill) & & & \\
\hline a. & $\begin{array}{l}\text { Keterampilan } \\
\text { Mengelola Diri Sendiri }\end{array}$ & 4.21 & 4.06 & 4.38 \\
\hline b. & $\begin{array}{l}\text { Keterampilan } \\
\text { Berbahasa }\end{array}$ & 3.97 & 3.64 & 3.99 \\
\hline c. & Keterampilan Analitis & 4.05 & 3.92 & 4.05 \\
\hline d. & Keterampilan Teknis & 4.17 & 4.11 & 4.11 \\
\hline 3 & Sikap (Attitude) & 4.21 & 3.90 & 4.08 \\
\hline 4 & Aspek Kinerja & 4.19 & 4.01 & 3.86 \\
\hline
\end{tabular}

Pada Tabel 6 di atas dapat di lihat bahwa nilai rata-rata maksimum pengaruh setiap unit kompetensi terhadap kinerja profesi pada bidang perencana, pengawas dan pelaksana berada pada skala di atas 3 yang artinya unit kompetensi tersebut relevan dan sangat relevan terhadap bidang pekerjaan yaitu perencanaan, pengawasan dan pelaksanaan konstruksi.

Tabel 7. Nilai Maksimum Pengaruh Unit Kompetensi Terhadap Kinerja Profesi

\begin{tabular}{|c|c|c|c|c|}
\hline \multirow{2}{*}{ No. } & \multirow{2}{*}{$\begin{array}{l}\text { Pengaruh Elemen } \\
\text { Kompetensi Terhadap } \\
\text { Kinerja Profesi }\end{array}$} & \multicolumn{3}{|c|}{$\begin{array}{l}\text { Bidang Pekerjaan / Nilai Mean Maksimum / Elemen } \\
\text { Kompetensi }\end{array}$} \\
\hline & & Perencana & Pengawas & Pelaksana \\
\hline 1 & Pengetahuan (Knowledge) & & & \\
\hline \multirow[b]{2}{*}{ a. } & \multirow{2}{*}{$\begin{array}{l}\text { Ilmu Pengetahuan Teknik } \\
\text { Sipil }\end{array}$} & 4.52 & 3.96 & 4.25 \\
\hline & & $\begin{array}{l}\text { Struktur bangunan } \\
\text { beton }\end{array}$ & Keairan & $\begin{array}{l}\text { Manajemen } \\
\text { konstruksi }\end{array}$ \\
\hline \multirow[b]{2}{*}{ b. } & \multirow[b]{2}{*}{$\begin{array}{l}\text { Pengetahuan Penerapan } \\
\text { Ilmu Dasar Teknik Sipil }\end{array}$} & 4.11 & 3.61 & 4.29 \\
\hline & & $\begin{array}{l}\text { Manajemen } \\
\text { keselamatan dan } \\
\text { kesehatan kerja (K3) }\end{array}$ & Manajemen risiko & $\begin{array}{lr}\text { Manajemen } & \\
\text { keselamatan } & \text { dan } \\
\text { kesehatan } & \text { kerja } \\
(\mathrm{K} 3) & \\
\end{array}$ \\
\hline \multirow{2}{*}{ c. } & \multirow{2}{*}{$\begin{array}{l}\text { Pengetahuan Spesifik dari } \\
\text { Jabatan }\end{array}$} & 4.59 & 4.25 & 4.29 \\
\hline & & Perencanaan bangunal & n sipil & Pengetahuan teknis \\
\hline 2 & Keterampilan (Skill) & & & \\
\hline \multirow{2}{*}{ a. } & \multirow{2}{*}{$\begin{array}{ll}\text { Keterampilan } & \text { Mengelola } \\
\text { Diri Sendiri } & \\
\end{array}$} & 4.41 & 4.21 & 4.50 \\
\hline & & Manajemen Waktu & & \\
\hline \multirow{2}{*}{ b. } & \multirow{2}{*}{ Keterampilan Berbahasa } & 4.26 & 3.96 & 4.32 \\
\hline & & Komunikasi yang efekt & & \\
\hline \multirow[b]{2}{*}{ c. } & \multirow[b]{2}{*}{ Keterampilan Analitis } & 4.11 & 4.04 & 4.25 \\
\hline & & $\begin{array}{l}\text { Perencanaan \& } \\
\text { pengorganisasian }\end{array}$ & $\begin{array}{l}\text { Pengambilan } \\
\text { keputusan }\end{array}$ & $\begin{array}{l}\text { Keterampilan } \\
\text { kepemimpinan }\end{array}$ \\
\hline d. & Keterampilan Teknis & 4.44 & 4.46 & 4.57 \\
\hline
\end{tabular}




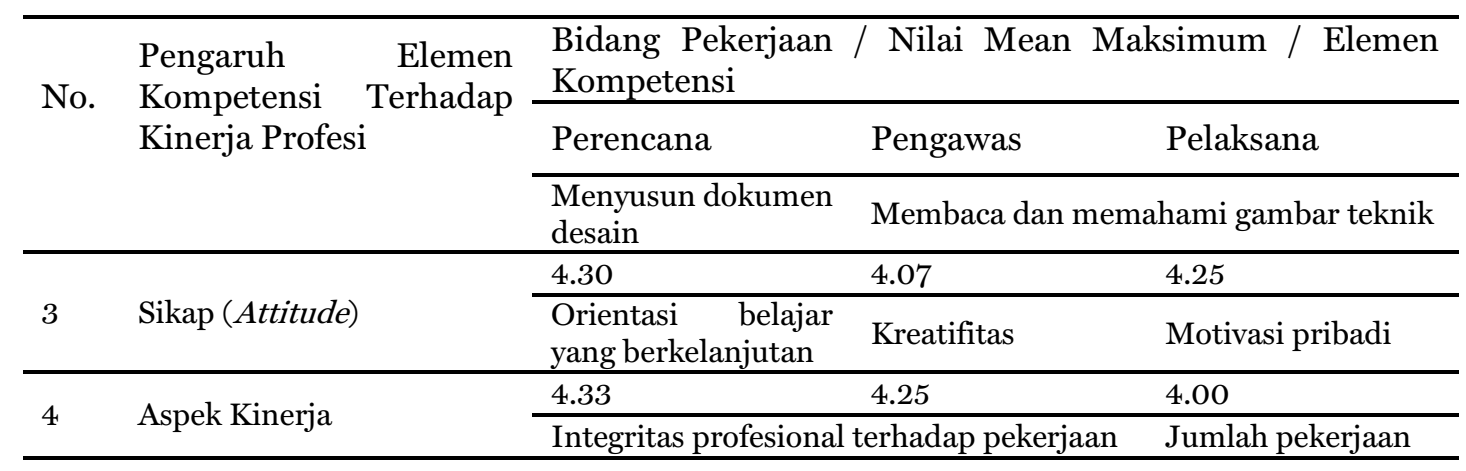

Pada Tabel 7 terlihat nilai rata-rata maksimum pengaruh setiap elemen kompetensi terhadap kinerja profesi pada bidang perencana, pengawas dan pelaksana berada pada skala relevan dan sangat relevan. Nilai rata-rata maksimum pengaruh terhadap kinerja profesi yang tertinggi sebesar 4.59, yang artinya tingkat pengaruh elemen kompetensi perencanaan bangunan sipil sangat berpengaruh terhadap kinerja profesi pada bidang pekerjaan perencana.

\subsubsection{Analisis Data Non Parametrik}

Andi (2015) menyatakan Uji dua sampel bertujuan untuk melakukan pengujian signifikansi perbedaan nilai dua sampel yang independent maupun untuk menguji mungkin tidaknya dua sampel independent berasal dari populasi yang sama. Dari hasil pengujian dapat dilihat bahwa terdapat beberapa variabel dengan nilai Sig. yang kecil dari 0.005 sehingga dapat disimpulkan :

- Pengaruh unit kompetensi terhadap kinerja profesi tidak berhubungan secara signifikan untuk variabel Y2 pada instansi Semen Padang dan dinas PU yaitu pengaruh elemen kompetensi pengetahuan struktur bangunan beton terhadap kinerja profesi. Hal ini karena Semen Padang merupakan bidang perencana dan dinas PU pengawas, pada perencana sangat memperhatikan kualitas dari desain yang dibuat, sementara pengawasan lebih dominan pada proyek sumber daya air.

- Pengaruh unit kompetensi terhadap kinerja profesi tidak berhubungan secara signifikan untuk variabel Y12, Y13, Y23 pada instansi Semen Padang dan Kontraktor yaitu pengaruh elemen kompetensi pengetahuan perencanaan bangunan sipil terhadap kinerja profesi, pengaruh elemen kompetensi pengetahuan perencanaan proses produksi terhadap kinerja profesi, pengaruh elemen kompetensi keterampilan bahasa asing terhadap kinerja profesi. Hal ini karena bidang pekerjaan yang berbeda.

- Relevansi unit kompetensi pada bidangnya dan pengaruhnya terhadap kinerja profesi tidak berhubungan secara signifikan untuk variabel X8 dan Y8 pada dinas PU dan Kontraktor yaitu relevansi dalam penggunaan elemen kompetensi pengetahuan K3 di bidangnya, pengaruh elemen kompetensi pengetahuan K3 terhadap kinerja profesi.

- Seluruh variabel penelitian kecuali yang di atas, pada ketiga instansi yaitu Semen Padang, Dinas PU dan Kontraktor berhubungan secara signifikan untuk variabel $\mathrm{X}$ (relevansi unit kompetensi di bidangnya) dan Y (pengaruh unit kompetensi terhadap kinerja profesi).

\subsection{Hubungan Unit Kompetensi Insinyur Sipil dan Kinerja Profesi}


Dari hasil penelitian tanggapan dari responden dan wawancara terhadap para pakar diperoleh bahwa terdapat hubungan yang linear antara relevansi unit kompetensi pada bidang pekerjaan dan pengaruh terhadap kinerja profesi. Semakin besar relevansi dalam penggunaan unit kompetensi terhadap bidang pekerjaan Insinyur Sipil maka akan semakin tinggi pula pengaruhnya terhadap kinerja profesi yang akan dihasilkannya dalam bekerja, dengan kata lain kinerja profesi Insinyur Sipil pada bidang pekerjaannya akan baik apabila memiliki unit kompetensi yang baik. Hasil tersebut didukung oleh beberapa penelitian di antaranya, Gusman (2011) menuliskan bahwa hubungan antara kompetensi dengan kinerja memiliki hubungan yang positif dengan hasil nilai yang signifikan. Semakin tinggi kompetensi yang dimiliki oleh auditor, semakin tinggi pula kinerja yang dihasilkannya. Dan Winanti (2011) hasil penelitiannya menunjukkan adanya pengaruh yang positif dan signifikan dari kompetensi terhadap kinerja karyawan.

\section{KESIMPULAN}

Berdasarkan hasil analisis pengolahan data dan pembahasan hasil penelitian, maka dapat disimpulkan bahwa :

a. Relevansi unit kompetensi Insinyur Sipil dengan nilai yang paling tinggi pada unit kompetensi keterampilan mengelola diri sendiri pada bidang perencana nilai mean sebesar 4.16 , bidang pengawas nilai mean sebesar 4.17 dan bidang pelaksana nilai mean sebesar 4.48.

b. Tingkat pengaruh unit kompetensi terhadap kinerja profesi dengan nilai mean tertinggi pada unit kompetensi keterampilan mengelola diri sendiri sebesar 4.21 bidang perencana, 4.38 bidang pelaksana dan pada keterampilan teknis sebesar 4.11 bidang pengawasan.

c. Terdapat hubungan yang linear antara relevansi unit kompetensi pada bidang pekerjaan dan pengaruh terhadap kinerja profesi. Semakin besar relevansi dalam penggunaan unit kompetensi terhadap bidang pekerjaan Insinyur Sipil maka akan semakin tinggi pula pengaruhnya terhadap kinerja profesi yang akan dihasilkannya dalam bekerja.

\section{DAFTAR KEPUSTAKAAN}

Ahadzie, D.K., Proverbs, D.G., and Olomolaiye, P. O. 2009. "Towards developing competency-based measures for project managers in mass house building projects in developing countries". Construction Management and Economics, Vol. 27, 89-102.

Aini, Nur. 2014. Hubungan Motivasi Kerja Dengan Kinerja Karyawan Pada PT. Pertamina Retail di Bright Surabaya. Situs :digilib.uinsby.ac.id/352/8/Bab\%202.pdf. (Diakses 14 November 2016)

Andi, Yogyakarta. 2015. Belajar Cepat Analisis Statistik Parametrik dan Non Parametrik dengan SPSS. Semarang : Wahana Komputer.

Boyatzis, Richard. E. Competencies in the 21st Century. Journal of Management Development. 2007. Vol 27, No. 1. 2007. pp. 5-12.

Chandra, Herry Pintardi. 2016. Variabel Kompetensi yang Dibutuhkan dalam Manajemen Konstruksi. ISBN: 978-602-60286-0-0. Univeritas Kristen Petra : Surabaya.

Elizarosma. 2008. Situs:digilib.itb.ac.id/files/disk1/628/jbptitbpp-gdl-elizarosma-31393-3-2008ts2.pdf (Diakses 19 Oktober 2016)

Gusman, Nadia Willia. 2011. Analisis Hubungan Kompetensi dengan Kinerja Auditor pada Badan Pemeriksa Keuangan Republik Indonesia. Institut Pertanian Bogor.

Hanafi, Mamduh. 2015. Modul 1 Konsep Dasar dan Perkembangan Teori Manajemen. Situs : Repository.ut.ac.id (Diakses 13 Mei 2017) 
Nofiyar. 2013. Structural Equation Model Untuk Hubungan Kompetensi Civil Engineer Pada Perusahaan Jasa Konsultan Perencana Proyek Telekomunikasi Dengan Kinerja Waktu. Master Tesis, Universitas Indonesia.

Sulistiawati, Rini. 2012. Pengaruh Upah Minimum terhadap Penyerapan Tenaga Kerja dan Kesejahteraan Masyarakatdi Provinsi di Indonesia.ISSN 1693 - 9093 Volume 8, Nomor 3, Oktober 2012. Universitas Tanjungpura : Pontianak.

Winanti, Marliana Budhiningtias. 2011. PENGARUH KOMPETENSI TERHADAP KINERJA KARYAWAN (SURVEI PADA PT. FRISIAN FLAG INDONESIA WILAYAH JAWA BARAT). Universitas Komputer Indonesia. Majalah Ilmiah UNIKOM Vol.7, No. 2. 